\title{
Hieracium maccoshiana, a new Scottish hawkweed related to $H$. dovrense (Section Alpestria, Asteraceae)
}

\author{
Timothy C. G. Rich \\ Department of Biodiversity \& Systematic Biology, National Museum Wales, Cardiff CF10 3NP, UK \\ Corresponding author: Timothy C. G. Rich (tim.rich@museumwales.ac.uk)
}

Academic editor: Vicki Funk | Received 19 January 2011 | Accepted 22 March 2011 | Published 30 May 2011

Citation: Rich TCG (2011) Hieracium maccoshiana, a new Scottish hawkweed related to H. dovrense (Section Alpestria, Asteraceae). PhytoKeys 3: 1-8. doi: 10.3897/phytokeys.3.920

\begin{abstract}
A new species of hawkweed Hieracium maccoshiana T.C.G.Rich sp. nov. is described. It is related to the Norwegian $H$. dovrense Fr., but differs in the shape and toothing of the stem leaves and in having glabroustipped ligules. It is endemic to the county of Sutherland, Scotland where it has been recorded from four sites. A lectotype of $H$. dovrense is designated.
\end{abstract}

\section{Keywords}

Asteraceae, dovrense, Endangered, Hieracium, lectotype, maccoshiana, new species, Norway, Scotland, Section Alpestria

\section{Introduction}

In 1897, E. S. Marshall and W. A. Shoolbred collected a hawkweed from rocks on the north side of Ben Loyal, Sutherland, Scotland, which they attributed to the Norwegian species, H. dovrense Fr. (Marshall and Shoolbred 1898). This identification has been followed in all subsequent accounts of Hieracium in Britain (Linton 1905; Pugsley 1948; Sell and West 1965, 1968; Sell and Murrell 2006). Four more sites were discovered in Sutherland at Creag na h-Uidhe, Foinaven and Rhiconich (two sites) in the 1960s and 1970s by A. G. Kenneth and A. McG. Stirling, and the plants were again attributed to $H$. dovrense. 
Hieracium dourense Fr. was described by E. M. Fries in 1848 from several alpine localities in Norway, particularly in the Dovre area (Fries 1848). Fries stated that he had seen Scottish specimens of ' $H$. amplexicaule' (presumably in its broad sense), which looked like his $H$. dovrense, but the material he saw has not been traced.

In 2005, D. McCosh suggested that I should visit one of the Rhiconich sites to see if $H$. dovrense was still present, and further visits were carried out in 2010 as part of a revision of Hieracium section Alpestria (Fr.) Arv.-Touv. in Britain. During this work I compared the Sutherland plants against a specimen in BM cited in Sell and West (1965) as a 'provisional lectotype' and other material. I came to the conclusion that they were not conspecific, and differed consistently in leaf shape and toothing and in hairiness of the ligule tips. The Sutherland plants also do not match the descriptions of any of the other subspecies of Zahn's (1921) general species $H$. dovrense or other Scandinavian material I have seen.

\section{Methods}

Material from Sutherland and of Norwegian $H$. dovrense was studied in the field in 2010 (see Supplementary file 1; Hieracium dovrense survey 2010; vouchers in NMW) and in the following herbaria in detail: MANCH, NMW, S and UPS. In addition, material from BM, CGE and $\mathrm{E}$ was also consulted. A description was drawn up following the format of Sell and Murrell (2006) for comparison with other British species.

The number of leaves on the stem is an important character in section Alpestria, but different taxonomists do not adopt a consistent method of counting leaves. The problem arises as leaves on the stem with inflorescences in their axils can also be termed bracts, which may or may not be counted. Furthermore, although there is a gradual transition from stems leaves to bracts, the smallest bracts at the top of the main stem may differ markedly in shape from the lower leaves and may be included or excluded. Here, all leaves and inflorescence bracts on the main stem are counted.

\section{Taxonomic treatment}

\section{Lectotype of $H$. dovrense Fr.}

Sell and West (1965: 93) discussed the complicated typification of $H$. dovrense in detail. They provisionally designated a lectotype from material in BM labelled 'Norveg. centr. a Dovre in Finmarkiarn copiose, M. N. Blytt', which was sent out as H. cydonaefolium Vill. in Fries's Set 11 no. 12 but noted that the specimen was badly damaged and that a fresh designation should be made if better quality original material were found (NOTE: Under Article 7.11 of the ICBN (McNeill et al. 2006) typifications only have priority if "definitely accepted as such by the typifying author"; usage of the 
word 'provisional' in this context means that the typification of Sell \& Murrell (1965: 93) can be superseded). Courtesy of Thomas Karlsson, an undamaged specimen from this set has now been found in $S$ (accession number S09.31085, http://andor.nrm.se/ kryptos/fbo/kryptobase/large/S09-031001/S09-31085.jpg) and is hereby designated as the lectotype of $H$. dovrense Fr.

\section{Hieracium maccoshiana T.C.G.Rich, sp. nov.} urn:Isid:ipni.org:names:77111568-1

http://species-id.net/wiki/Hieracium_maccoshiana

Figs 1, 2 D-N

Rosula basalia sub anthesi fere absenti. Foliis caulinis 4-8 ellipticis dentibus magnis. Pedunculis pilis multis stellatis pilis eglandulosis simplicibus multis pilisque glandulosis paucis. Bracteis involucralibus 2-2.5 mm latitudinis pilis stellatis paucis pilis eglandulosis simplicibus multis pilisque glandulosis multis. Ligulis apice glabris. Stylis obscuris.

Holotype: Scotland. Sutherland: by small stream, Allt na Cuile, Rhiconich, 58.4470, -4.9300, $150 \mathrm{~m}$ alt., 26 July 2010, M. Jannink (NMW, accession number V.2010.1.213).

Description. Stem to $50 \mathrm{~cm}$, pale green, slightly purple-tinted below, slender to fairly robust; stellate hairs sparse and mainly above; simple eglandular hairs long, pale, sparse and glabrescent to dense (especially below); glandular hairs very small, occasional; sparsely and minutely puberulous. Basal leaves absent or withering before or up to flowering time or rarely persistent, few. Lamina elliptical or subrotund; apex obtusemucronulate; base attenuate; margins remotely denticulate to coarsely dentate; with a few, pale, medium simple eglandular hairs above and below or nearly glabrous above. Petioles winged and broadened at base, with numerous medium to long, pale simple eglandular hairs. Stem leaves and inflorescence bracts (3-)4-8, 2-10 × 0.8-3.5 cm, gradually decreasing in size upwards, pale green on upper surface, paler beneath. Lamina of the lower leaves elliptical; apex obtuse-mucronulate to acute; base attenuate; margins denticulate to sharply and irregularly dentate with ascending teeth; petiole winged, semiamplexicaul. Lamina of the median leaves elliptical; apex obtuse-mucronulate to acute; base rounded or abruptly contracted, sessile, semiamplexicaul; margins denticulate to sharply and irregularly dentate with large or small, ascending, mammiform teeth. Lamina of the upper leaves lanceolate; apex acute to acuminate; base cuneate, sessile, semiamplexicaul, margins denticulate to shallowly dentate. All stem leaves with stellate hairs few to sparse on both surfaces; simple eglandular hairs few to numerous below and nearly glabrous above, pale, medium. Inflorescence usually with $2-9(-12)$ capitula, rather compactly cymose. Peduncles $1-5 \mathrm{~cm}$ (acladium $0.3-2 \mathrm{~cm}$ ), suberect, slender; stellate hairs sparse to dense; simple eglandular hairs few to numerous, short to medium, dark-based; glandular hairs few, very short, black. Capitula $20-30(-45) \mathrm{mm}$ in diameter, subtruncate at base. Involucral bracts 9-11 × (1.7-)2.0-2.5 mm (the outermost from $c .5 \mathrm{~mm}$ long), all linear-lanceolate, blackish-green; apex obtuse; stellate hairs 


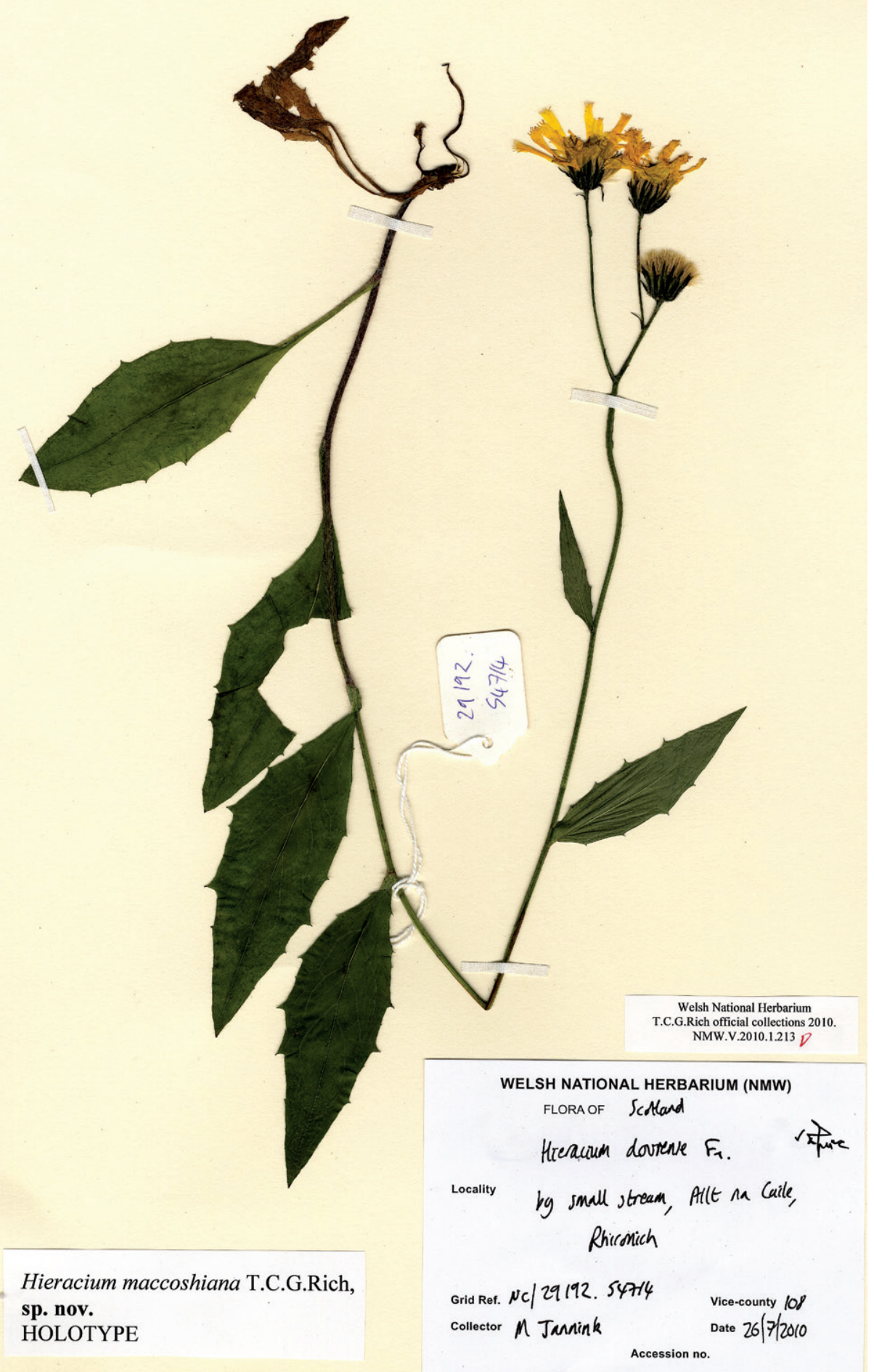

Figure I. Holotype of Hieracium maccoshiana (NMW). 

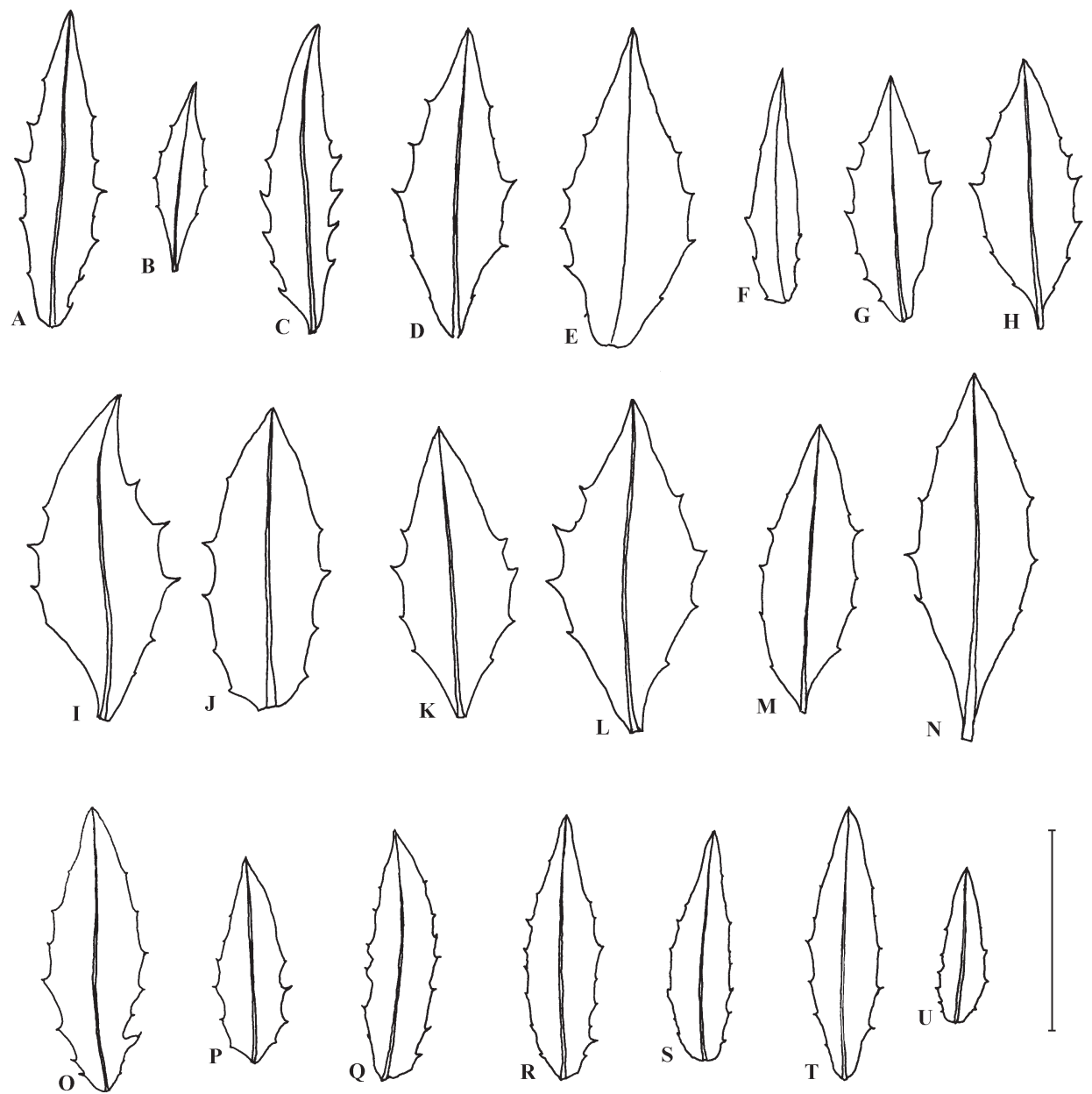

Figure 2. Middle stem leaves. A-C possible H. maccoshiana. A-B Ben Loyal (NMW 28.131.5185). C Ben Loyal (BM). D-N H. maccoshiana. D-F Rhiconich gorge (NMW V.2005.1.159). G-H Foinaven (CGE). I-L Rhiconich (CGE). M-N Craig na H'Uidhe (CGE). O-U H. dovrense, Drivstua, Dovref, Norway (S). O-Q S09-16213. R S09-16217. S S09-16224. T-U S09-16222. Scale bar $5 \mathrm{~cm}$.

sparse, often with a tuft at the apex; simple eglandular hairs many, short to medium, dark-based; glandular hairs many, very short, black. Ligules yellow, glabrous-tipped. Styles discoloured. Achenes 4.0-4.5 mm, blackish-brown. Margins of receptacle pits long-dentate. Chromosome number $2 \mathrm{n}=36$ (cf. Sell and Murrell 2006, as H. dovrense).

Distribution. Endemic to Sutherland, Scotland, where it is known from four sites in Sutherland: in a gorge and on a burn side near Rhiconich; on a burn side in Coire Dùail, Foinaven; and on rocks at Creag na h-Uidhe (Fig. 3). The status of plants from Ben Loyal remains to be clarified when it has been refound in the field. 


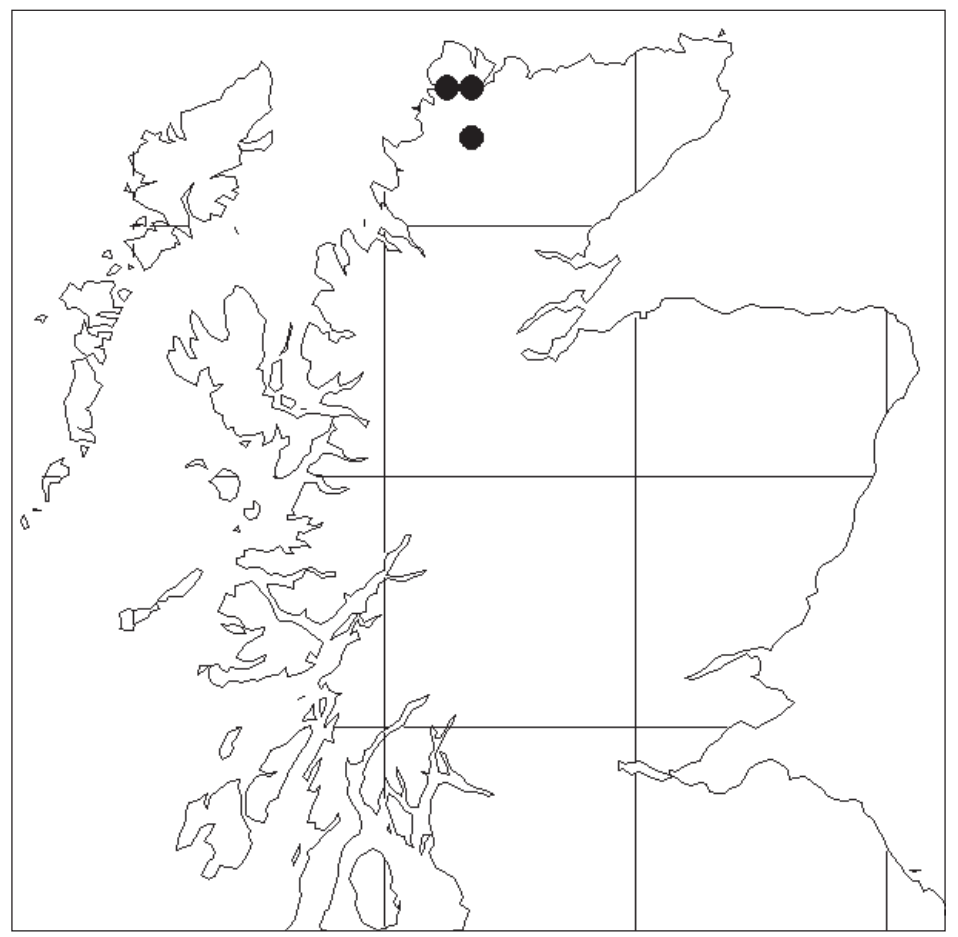

Figure 3. Distribution of Hieracium maccoshiana in Scotland.

Ecology. Mountain cliff ledges and rocks, in rocky ravines and on riversides. It mostly occurs out of the reach of large herbivores such as deer or sheep as, like most leafy hawkweeds, is likely to be selectively eaten. The altitudes range from 130-414 m. It flowers from late July to August, and is probably apomictic. Some plants may produce sparse pollen and others none (Thomas et al. in press).

Etymology. The epithet honours David J. McCosh for his work in mapping British and Irish Hieracium taxa over the last 30 years, and for mentoring me. The spelling 'maccoshiana' follows recommendation 60C.5.a of the International Code of Botanical Nomenclature (Vienna Code McNeil et al. 2006).

Conservation status. Surveys in 2010 revealed about 60 plants in four sites (see supplementary file 1: Hieracium dovrense survey 2010). It is thus best considered at IUCN (2001) threat status 'Endangered' due to the small population size.

\section{Discussion}

Hieracium maccoshiana is characterized by the absence of a basal rosette at flowering, the relatively few (4-8), elliptical stem leaves with large teeth, the relatively hairy peduncles, the relatively broad $(2-2.5 \mathrm{~mm})$ involucral bracts with few stellate hairs but many simple and glandular hairs, the glabrous ligule tips and the discoloured styles. 
Hieracium maccoshiana is quite variable in hairiness and in size, with very small plants growing on dry, exposed rocks, and larger plants in sheltered situations. The basal rosettes have usually withered by flowering time but may persist when sheltered in tall vegetation. Material from Rhiconich cultivated by J. R. N. Mills became much more robust with more stem leaves with larger teeth, and developed many branches down the stem with more capitula (MANCH).

Plants from Ben Loyal tend to have slightly narrower, elliptical leaves (Fig. 2, A-C) and look more similar to Norwegian $H$. dovrense than plants from the other populations but have glabrous ligule tips. I have provisionally grouped them with $H$. maccoshiana but have been unable to refind them in the field yet to carry out more detailed studies.

No British species is closely allied to $H$. maccoshiana. Four other section Alpestria species occur in mainland Scotland and England. Hieracium perthense F.N.Williams (H. carpathicum auct. angl.) and $H$. dewari Syme have many more (6-20), broader, more hairy stem leaves, narrower $(1.1-2.0 \mathrm{~mm})$ involucral bracts with numerous glandular hairs, and hairy tips to the ligules. Hieracium mirandum P.D.Sell \& C. West has ovate to lanceolate stem leaves with more densely hairy peduncles, and narrower (1.5$2.0 \mathrm{~mm}$ ), more sparsely hairy involucral bracts. Hieracium solum P.D.Sell \& C.West has a basal rosette at flowering, a few, nearly entire stem leaves and nearly glabrous peduncles. Sixteen section Alpestria species occur in Shetland, of which $H$. australius (Beeby) Pugsley is most similar to $H$. maccoshiana but has generally more (5-12) stem leaves which are more hairy on the upper surface, has larger (to $c .35 \mathrm{~mm}$ ) capitula, and has less hairy peduncles without glandular hairs.

Hieracium maccoshiana differs from $H$. dovrense having elliptical middle stem leaves, typically (14-)25-40 mm wide and 2.0-2.8 times as long as wide, with few, large teeth (Fig. 2), and glabrous ligule tips. Hieracium dovrense has elliptical to narrowly elliptical middle stem leaves $13-25 \mathrm{~mm}$ wide and 2.6-3.4 times as long as wide with more, smaller teeth (Fig. 2) and ciliate ligule tips. Sell \& West (1965) described the achenes of Scandinavian plants as 2.0-2.5 mm long and dark brown but I suspect these were immature as fruits of both species I have seen are very similar.

Unfortunately, when Fries described $H$. dovrense, he cited the earlier name $H$. cydonae[ii]folium Vill. as a synonym thus invalidating the name. As Stace (1998) designated $H$. dovrense as the type species of section Alpestria, a separate proposal will be required to conserve the name $H$. dovrense Fr.

\section{Conclusion}

Hieracium maccoshiana is a new endemic species from Scotland. It is a member of Hieracium section Alpestria and differs from $H$. dovrense within which it has previously been included by the shape and toothing of the stem leaves and in having glabrous ligule tips. The status of plants from Ben Loyal remains to be clarified. 


\section{Acknowledgements}

I would like to thank Pat and Ian Evans, Nicholas Hind, Mats Hjertson, John Hunnex, Rob Huxley, Mark Jannink, Thomas Karlsson, Theo Lloyd, David McCosh, Andy McVeigh, David Price, Walter Scott, Leander Wolstenholme and the Keepers of BM, CGE, E, K, MANCH, O, S and UPS for access to material. The map was plotted using DMAP by Alan Morton.

\section{References}

Fries E (1848) Symbolae ad Historiam Hieraciorum. Uppsala, 128-129.

IUCN (2001) IUCN Red List Categories. Version 3.1. International Union for Conservation of Nature, Gland.

Linton WR (1905) An Account of the British Hieracia. London, 1-96.

Marshall ES, Shoolbred WA (1898) Notes of a tour in N. Scotland, 1897. Journal of Botany, British and foreign 36: 166-177.

McNeill J, Barrie FR, Burdet HM, Demoulin V, Hawksworth DL, Marhold K, Nicolson DH, Prado J, Silva PC, Skog JE, Wiersema JH, Turland NJ (2006) International Code of Botanical Nomenclature (Vienna Code). Regnum Vegetabile 146. ARG Gantner Verlag KG.

Pugsley HW (1948) A Prodromus of the British Hieracia. Journal of the Linnean Society of London (Botany) 54: 1-356.

Sell PD, Murrell G (2006) Flora of Great Britain and Ireland, volume 4. Cambridge University Press, Cambridge, 218-421. doi: 10.1017/CBO9780511541841

Sell PD, West C (1965) A revision of the British species of Hieracium section Alpestria [Fries] F. N. Williams. Watsonia 6: 85-105.

Sell PD, West C (1968) Hieracium L. In: Perring FH (Ed) Critical Supplement to the Atlas of the British flora. BSBI, London, 75-131.

Stace CA (1998) Sectional names in the genus Hieracium (Asteraceae) sensu stricto. Edinburgh Journal of Botany 55: 417-441. doi: 10.1017/S0960428600003279

Thomas S, Bailey J, Rich TCG (in press) Pollen and cytological studies in Hieracium section Alpestria (Asteraceae). Nordic Journal of Botany.

Zahn KH (1921-1923) Compositae - Hieracium, in Engler, A. Das Pflanzenreich 77 (IV, 280). Leipzig. 